\title{
Preobrazba degradiranih urbanih območij in družbena vzdržnost: primerjalna študija urbane regeneracije in urbane prenove $v$ Barceloni in Seulu
}

Preobrazba degradiranih urbanih območij je pomembna za krepitev družbene vzdržnosti v lokalnih okoljih, poleg tega je ključna za privabljanje novih naložb v mesta. Toda pri špekulativnem urbanem razvoju se pogosto prezre družbeni pomen lokalnih okolij, ki se dojemajo le kot ekonomske dobrine, ki jim je mogoče odvzeti zgodovinske, družbene in simbolne pomene ter jih pretvoriti $\mathrm{v}$ tržno blago. $\mathrm{V}$ članku avtor proučuje nekoliko protislovno vlogo preobrazbe degradiranih območij v mestih, pri čemer primerja Barcelono in Seul, mesti s precej različnimi zgodovinskimi, kulturnimi in institucionalnimi značilnostmi. Območje dejavnosti 22@v Poblenouju in Novo sosesko Wangsimni v Seulu obravnava kot študiji primera, $s$ katerima poskuša ugotoviti, kako se urbana regeneracija in prenova umeščata $\mathrm{v}$ posamezno lokalno okolje in katere posledice imata za družbeno vzdržnost. Čeprav se primera razlikujeta glede na načrtovalski pristop, deležnike in institucionalni okvir, izsledki kažejo, da so posledice za družbeno vzdržnost pri obeh podobne. V članku avtor ugotavlja, da sta bila oslabljena družbena kohezija in premajhno sodelovanje javnosti posledica špekulativnega urbanega razvoja, pri čemer sta se urbana regeneracija in prenova uporabili za privabljanje naložb, krepitev gospodarske konkurenčnosti in izboljšanje globalne privlačnosti mesta, namesto za reševanje raznovrstnih lokalnih vprašanj.

Ključne besede: sodelovanje javnosti, družbena kohezija, družbena vzdržnost, urbana prenova, urbana regeneracija 


\section{Uvod}

Mesta tekmujejo pri privabljanju naložb, ustvarjanju delovnih mest, organiziranju dogodkov in privabljanju turistov, s čimer naj bi se okrepila njihova gospodarska rast in urbani razvoj ter izboljšala kakovost življenja. Toda zelo malo dokazov kaže, da takšno tekmovanje prinaša enake koristi za vse. Nasprotno, koristi so pogosto neenakomerno razporejene med družbenimi skupinami v mestu (Brenner idr., 2012; Harvey, 2012). Poleg tega naj bi tekmovalna urbana politika, ki daje prednost pretvorbi javnega prostora $\mathrm{v}$ tržno blago, privatizaciji javnih dobrin in storitev, deregulaciji urbanističnega načrtovanja in gradnji ikoničnih projektov skupaj s trženjem mesta, povzročala degradacijo okolja, družbene in gospodarske neenakosti ter kršenje državljanskih pravic (Short, 2004; Mayer, 2007). Tovrsten tržno usmerjeni urbani razvoj obravnava lokalna okolja le kot ekonomske dobrine, ki jim je mogoče odvzeti zgodovinske, družbene in simbolne pomene ter jih pretvoriti v tržno blago (Balibrea, 2001; Short, 2004; Križnik, 2011). Preobrazba degradiranih urbanih območij je zato postala ključna za privabljanje novih naložb v mesta (Smith, 2002; Shin in Kim, 2016), prenova teh območij pa je pomembna tudi za krepitev družbene razsežnosti trajnostnega razvoja mest (Manzi idr., 2010; Colantonio in Dixon, 2011; Ho idr., 2012).

Avtor v članku proučuje nekoliko protislovno vlogo preobrazbe degradiranih urbanih območij v mestih, pri čemer primerja Barcelono in Seul, mesti s precej različnimi zgodovinskimi, kulturnimi in institucionalnimi značilnostmi. Predhodne raziskave kažejo, da se je kljub tem razlikam preobrazba urbanih območij, ki sta jih mestni upravi Barcelone in Seula obravnavali kot nerazvita, pogosto izkoriščla za privabljanje naložb, krepitev gospodarske konkurenčnosti in izboljšanje splošne privlačnosti Barcelone (Marshall, 2000; Balibrea, 2001; Arbaci in Tapada-Berteli, 2012; Dot Jutgla idr., 2012; Charnock idr., 2014) in Seula (Cho, 2008; Kim, 2010; Križnik, 2011; Shin in Kim, 2016). To se je javno upravičevalo kot strateško pomembno za mesto in domnevno koristno za vse prebivalce (Ajuntament de Barcelona, 2000, 2012; SMG, 2005, 2010). Podobnosti v izkoriščanju in upravičevanju tovrstne preobrazbe mest so izhodišče za primerjavo preobrazbe degradiranih urbanih območij v Barceloni in Seulu ter njenih posledic za družbeno vzdržnost lokalnega okolja.

Čeprav je urbani razvoj v Barceloni in Seulu pogosto predmet raziskav, je bil redko obravnavan s primerjalnega vidika (izjeme vključujejo raziskave, ki so jih opravili Uršič in Križnik, 2012; Colantonio idr., 2014; Križnik, 2014). Članek se začne z razpravo o odnosu med urbanim razvojem in družbeno vzdržnostjo, na podlagi česar avtor vzpostavi okvir za vrednotenje posledic urbanega razvoja za družbeno vzdržnost lokalnega okolja. Nato primerja Barcelono in Seul glede na njun položaj $\mathrm{v}$ svetovnem in nacionalnem omrežju mest ter njune načrtovalske pristope in institucionalne okvire. Območje dejavnosti 22@ (Activity District 22@, krajše 22@) v Poblenouju in Nova soseska Wangsimni (Wangsimni New Town ali WNT) v Seulu sta obravnavana kot poglobljeni študiji primerov urbane regeneracije v Barceloni oziroma urbane prenove v Seulu z vidika načrtovalskega pristopa, deležnikov in posledic za družbeno vzdržnost. ${ }^{[1]}$ Članek se konča s povzetkom rezultatov, sklepom in predstavitvijo omejitev raziskave.

\section{Urbani razvoj in družbena vzdržnost}

Trajnostni urbani razvoj je navadno obravnavan v smislu trojnosti, v skladu s katero naj bi bila trajnostna gospodarska rast mest uravnotežena $\mathrm{z}$ varovanjem okolja in družbeno enakostjo (Mayer in Knox, 2006: 324). Uravnoteženje gospodarstva, okolja in družbene enakosti zahteva pogajanja med deležniki, kar kaže, da vsebuje trajnostni urbani razvoj tudi politično razsežnost. V preteklosti se je trajnostni urbani razvoj nanašal le na gospodarsko in okoljsko razsežnost, zdaj pa je široko uveljavljen večrazsežnostni pristop, ki priznava pomen družbene vzdržnosti za dolgoročen trajnostni urbani razvoj (Dempsey idr., 2011; Dujon idr., 2013). Eden od razlogov za razmeroma malo pozornosti, ki je je bila v preteklosti deležna družbena vzdržnost, je povezan z nezadostnim razumevanjem odnosa med družbeno vzdržnostjo in urbanim razvojem. Drug razlog so pogosto neoprijemljive družbene posledice urbanega razvoja, ki prej ali slej povzročijo težave pri izvajanju in vrednotenju urbane politike, ki spodbuja družbeno vzdržnost.

Colantonio in Dixon (2001: 24) trdita, da je treba družbeno vzdržnost obravnavati v smislu tradicionalnih področij in načel socialne politike, kot sta enakost in zdravje, ter porajajočih se vprašanj, povezanih s sodelovanjem javnosti, potrebami, socialnim kapitalom, gospodarstvom, okoljem in v zadnjem času tudi s pojmi sreče, dobrega počutja in kakovosti življenja. Urbana politika, katere namen je okrepiti družbeno vzdržnost, bi morala po njunem mnenju izboljšati kakovost vsakdanjega življenja, spodbujati enake možnosti za družbene skupine z različnim ekonomskim, socialnim in kulturnim ozadjem, spodbujati družbeno vključenost z reševanjem ekonomske, socialne in politične izključenosti, vzdrževati obstoječe družbene in kulturne strukture v lokalnih okoljih, spodbujati sodelovanje javnosti v procesih odločanja in podpirati samoupravljanje lokalnih okolij. Zato je za krepitev družbene vzdržnosti v mestih potrebno povezovanje najrazličnejših politik, vključno $s$ tistimi, ki se osredotočajo na gospodarstvo, socialno varstvo, izobraževanje, okolje in urbanizem (Dempsey idr., 2011). 
Načrtovalski pristopi, namenjeni preobrazbi degradiranih urbanih območij, kot sta urbana prenova in urbana regeneracija, so pomembna orodja za reševanje vprašanja družbene vzdržnosti v mestih (Williams in Dair, 2007; Manzi idr., 2010; Colantonio in Dixon, 2011; Ho idr., 2012). Poleg zagotavljanja cenovno dostopnih stanovanj, javnih storitev in infrastrukture lahko preobrazba teh območij ublaži družbene neenakosti in krepi družbeno vključenost $\mathrm{v}$ lokalnih okoljih z ustvarjanjem vključujočih prostorov, kjer se lahko srečujejo družbene skupine z različnimi ozadji ter se lahko ustvarjajo in poustvarjajo skupnostno življenje in skupne identitete (Forrest in Kearns, 2001). Urbana prenova (ang. urban redevelopment) se osredotoča na fizično izboljšanje in spreminjanje podobe degradiranih urbanih območij, ki se delno ali popolnoma porušijo in nadomestijo z novogradnjami. To pogosto vodi $\mathrm{v}$ množično razseljevanje prebivalcev in razpad njihovih socialnih mrež. Nasprotno je namen urbane regeneracije (ang. urban regeneration) gospodarska, družbena, okoljska in fizična preobrazba degradiranih urbanih območij, pri čemer se novi objekti in storitve povežejo $\mathrm{z}$ obstoječim družbenim in urbanim tkivom (Cho in Križnik, 2017; Roberts idr., 2017). Ho idr. (2012: 127) menijo, da je takšen postopni in celostni pristop primernejši za krepitev trajnosti grajenega okolja.

Sodelovanje javnosti je splošno prepoznano kot ključno za krepitev družbene vzdržnosti (Irvin in Stansbury, 2004; Dempsey at el., 2011). Prispeva $k$ boljšemu zavedanju deležnikov o različnih interesih, težavah in priložnostih v lokalnih okoljih ter $\mathrm{k}$ učenju skupnega reševanja teh izzivov. Tako se lahko izboljša kakovost načrtovanja, upravičijo sprejete odločitve in prebivalce spodbudi, da prostore, ki se preobrazijo z njihovim sodelovanjem, aktivno uporabljajo in jih vzamejo za svoje (Cerar, 2014). Cho in Križnik (2017: 151) prepoznavata nujnost gradnje trdnega partnerstva med državo in civilno družbo kot pomemben korak k uspešnemu urbanemu razvoju, ki temelji na skupnosti, in močnejši družbeni vzdržnosti v mestih. Načrtovalski pristopi, katerih namen je okrepiti družbeno vzdržnost, po njunem mnenju spodbujajo aktivno vključevanje prebivalcev v procese odločanja in prispevajo $\mathrm{k}$ družbeno bolj povezanim lokalnim okoljem. Značilnosti takih lokalnih okolij so majhna družbena neenakost, močne socialne vezi in zaupanje ter dobro vzpostavljena komunikacija in sodelovanje med prebivalci in javnimi ustanovami (Larsen, 2013). Preobrazba degradiranih urbanih območij lahko tako izboljša družbene odnose, zaupanje in solidarnost med različnimi deležniki ter zaupanje v javne ustanove, za kar Manzi idr. (2010: 18) trdijo, da so ključni pojmi in vodilna načela družbene vzdržnosti v lokalnih okoljih.

Številna mesta, kjer so prebivalci izključeni iz procesov odločanja, se spopadajo s težavami pri vzdrževanju družbene in teritorialne kohezije (Brenner idr., 2012). Harvey (1989: 13) trdi, da ti problemi izvirajo predvsem iz urbanega podjetnišstva in uničujočega tekmovanja med mesti. Urbani razvoj namreč postaja vse bolj špekulativen in pomemben predvsem za mobilizacijo nepremičninskih trgov v mestih kot sredstev za kopičenje kapitala (Smith, 2002: 446). Mesta z razmeroma obrobnim položajem v svetovnem omrežju mest so navadno izpostavljena močnejšim pritiskom glede kopičenja kapitala kot vodilna središča (Gugler, 2004; Short, 2004; Harvey, 2012). Taylor (2004) jih imenuje mesta, ki si želijo postati globalna mesta (ang. wannabe global cities), s čimer izpostavlja njihovo željo po spremembi vzpostavljenih odnosov v svetovnem omrežju mest. Tekmovanje med mesti in posledični špekulativni urbani razvoj lahko negativno vplivata ne le na družbeno vzdržnost lokalnih okolij, temveč tudi na dolgoročno sposobnost mesta, da se učinkovito spoprijema z družbenimi, gospodarskimi in okoljskimi izzivi (Wolfram, 2018).

\section{Metodologija}

Sassnova (2001: 348) pojasnjuje, da v nasprotju s klasičnim primerjalnim pristopom primerjanje mest $\mathrm{v}$ svetovnem omrežju mest zahteva novo metodologijo; takšno, ki ne temelji na poenotenju študij primerov, temveč poskuša slediti danemu sistemu ali dinamiki in njunim značilnim pojavnim oblikam $\mathrm{v}$ številnih državah. V tem članku avtor upošteva njen predlog ter primerja Barcelono in Seul, da bi bolje razumel posledice špekulativnega urbanega razvoja za družbeno vzdržnost. Obe mesti sta v preteklosti zasedali podoben položaj v svetovnem in lastnem nacionalnem omrežju mest. Predhodne raziskave kažejo, da je to vplivalo na preobrazbo degradiranih urbanih območij, ki so jo izkoristili predvsem za privabljanje naložb, krepitev gospodarske konkurenčnosti in izboljšanje globalne privlačnosti Barcelone in Seula (Marshall, 2000; Balibrea, 2001; Cho, 2008; Kim, 2010; Križnik, 2011; Arbaci in Tapada-Berteli, 2012; Dot Jutgla idr., 2012; Charnock idr., 2014; Shin in Kim, 2016). To se je v javnosti v glavnem upravičevalo kot strateško pomembno za mesto in domnevno koristno za vse prebivalce (Ajuntament de Barcelona, 2000, 2012; SMG, 2005, 2010).

Podobno izkoriščanje in upravičevanje urbanega razvoja $\mathrm{v}$ obeh obravnavanih mestih v povezavi z njunim položajem $\mathrm{v}$ svetovnem in lastnem nacionalnem omrežju mest ponujata metodološko izhodišče za medkulturno primerjavo preobrazbe degradiranih območij v Barceloni in Seulu. Čeprav sta bili obe mesti že obravnavani primerjalno, so se predhodne študije osredotočale na vpliv medmestnega tekmovanja na upravljanje mesta (Uršič in Križnik, 2012), pomen večnivojskega upravljanja mesta za njegovo gospodarsko prožnost (Colantonio idr., 2014) ali na odzive prebivalcev na globalizacijo Barcelone in Seula (Križnik, 2014). V teh študijah je bilo manj pozornosti 
namenjene vplivu urbanega razvoja na družbeno vzdržnost, ki je sicer prepoznana kot eden največjih prihodnjih izzivov mest (Dempsey idr., 2011; Wolfram, 2018). V tem članku zato avtor območji 22@v Barceloni in WNT v Seulu proučuje kot poglobljeni študiji primera urbanega razvoja, da bi ugotovil, kako se načrtovalski pristopi umeščajo $\mathrm{v}$ posamezno lokalno okolje in katere posledice imajo za družbeno vzdržnost. Vrednotenje te vzdržnosti se osredotoča na družbeno kohezijo in na vključevanje prebivalcev v procese odločanja, ki sta prepoznana kot ključni načeli družbene vzdržnosti (Forrest in Kearns, 2001; Irvin in Stansbury, 2004; Manzi idr., 2010; Cho in Križnik, 2017).

Terenska raziskava je zajemala številne obiske Poblenouja in Wangsimnija med letoma 2006 in 2012, ki so bili namenjeni opazovanju družbene in urbane preobrazbe teh dveh območij. V tem obdobju so bili izvedeni polstrukturirani intervjuji z 12 intervjuvanci iz Barcelone in 16 iz Seula, pri čemer je vsak izmed njih pripadal eni od petih glavnih skupin deležnikov. $^{[2]}$ Dve anketi, ki sta vključevali 148 vprašanih iz Poblenouja oziroma 95 iz Wangsimnija, sta bili izvedeni v letih 2006 in 2007, da se primerjajo posledice preobrazbe obeh lokalnih okolij za vsakdanje življenje. Anketi sta temeljili na neverjetnostnem kvotnem vzorčenju, pri katerem so bili anketiranci izbrani glede na spol, starost, kraj rojstva, izobrazbo in lastništvo stanovanja. ${ }^{[3]}$ Ker ta metoda ne omogoča posplošitve rezultatov ankete na celotno populacijo, sta bili anketi dopolnjeni s poglobljenimi intervjuji in obsežno analizo sekundarnih virov. Ti so med drugim vključevali dokumente in poročila mestnih uprav, raziskave, povezane z urbanistično politiko in prostorskim načrtovanjem, in razne zgodovinske zapise o Poblenouju in Wangsimniju. O izsledkih raziskave je bil opravljen tudi posvet s strokovnjaki na terenu v obeh mestih, $s$ čimer se je avtor izognil kulturni pristranskosti pri razumevanju in vrednotenju podatkov, kar velja za glavno težavo medkulturnih primerjalnih študij (Hantrais in Mangen, 1996).

\section{4 Študija primera: Barcelona in Seul 4.1 Institucionalni okvir urbanega razvoja Barcelone in Seula}

Barcelona in Seul sta prestolnici Katalonije oziroma Južne Koreje. Obe mesti sta v svetovnem omrežju mest zasedali podoben položaj, ki ga je Gugler (2004) opisal kot sekundarno svetovno mesto. Taylor (2004) je Barcelono in Seul na podlagi analize naprednih storitvenih dejavnosti podobno uvrstil na 32. oziroma 41. mesto glede na njun položaj v svetovnem omrežju mest. Tudi drugi avtorji so v preteklosti prepoznali razmeroma obroben položaj Barcelone in Seula v svetovnem omrežju mest (Beaverstock idr., 1999; Alderson idr., 2010; Csomós in Derudder, 2013). V nasprotju z vodilnimi središči, kot so New York, Lon- don ali Tokio, ki jih je Sassnova (2001: 3) označila za poveljevalne točke v organizaciji svetovnega gospodarstva, pomen Barcelone in Seula v svetovnem omrežju mest izhaja iz njune vloge pri povezovanju nacionalnega gospodarstva s svetovnimi trgi. Barcelona je primer tega, čemur Taylor (2004) pravi »inner wannabe city «. Zadnjih dvajset let je bil strateški cilj mestne uprave izzvati vodilni položaj Madrida v nacionalnem omrežju mest z razvijanjem panog, ki temeljijo na inovacijah, znanju in ustvarjalnosti, ter z izboljšanjem komunikacijske, logistične in prometne infrastrukture (Ajuntament de Barcelona, 2012). Mesto si je pri tem prizadevalo izboljšati svoj položaj ne samo v odnosu do Madrida, temveč tudi do drugih evropskih in še posebno sredozemskih mest (Monclús, 2003; OECD, 2009). Seul pa je primer mesta, ki ga Taylor imenuje $»$ outer wannabe city«, saj je s spodbujanjem naprednih storitvenih dejavnosti in panog, ki temeljijo na znanju in kulturi, poskušal tekmovati s Tokiem, Hongkongom in Pekingom (Taylor, 2004). Čeprav ima Seul visoko razvito komunikacijsko in prometno infrastrukturo, ostaja izboljšanje kakovosti življenja glavni strateški cilj mestne uprave (OECD, 2005; SMG, 2013).

V tem smislu sta se obe mesti v zadnjih desetih letih uspešno spremenili iz nacionalnih industrijskih prestolnic v pomembni postindustrijski globalni mesti. Še zlasti Seulu je uspelo močno okrepiti svojo globalno poveljevalno in nadzorno funkcijo, Barcelona pa ohranja svoje konkurenčne prednosti kljub zmanjševanju pomena evropskih mest na splošno (Csomós in Derudder, 2013: 346). Globalizacija je tako okrepila njuno vlogo nacionalnih gospodarskih, družbenih, kulturnih in političnih središč, kar je privedlo do še večje koncentracije prebivalstva ter finančne in politične moči. Leta 2014 je približno $63 \%$ prebivalcev Katalonije živelo v barcelonski metropolitanski regiji, približno 48 \% Južnokorejcev pa je živelo v regiji nacionalne prestolnice Seul (Ajuntament de Barcelona, 2015; SMG, 2015a). Barcelona ni samo prestolnica Katalonije, je tudi drugo največje špansko mesto in rivalstvo z Madridom je vedno močno vplivalo na njen urbani razvoj (Monclús, 2003). Obe mesti ostajata privlačni za velike naložbe, panoge, ki temeljijo na znanju in kulturi, napredne storitvene dejavnosti, nova delovna mesta ter ključne raziskovalne, razvojne in izobraževalne ustanove v Kataloniji in Južni Koreji, čeprav se je $\mathrm{v}$ tem pogledu tudi pomen metropolitanskih regij v zadnjem času povečal (Choe, 2005; OECD, 2005, 2009).

Ta posebni položaj Barcelone in Seula v svetovnem in lastnem nacionalnem omrežju mest vpliva tudi na preobrazbo degradiranih urbanih območij ter postaja čedalje bolj ključen za privabljanje naložb v obe mesti (Charnock idr., 2014; Shin in Kim, 2016). Preobrazba degradiranih urbanih območij v Barceloni sega v pozno 19. stoletje, ko so bili precej spremenjeni večji deli mestnega središča. $V$ skladu s to tradicijo je mestna uprava $\mathrm{v}$ osemdesetih letih 20. stoletja uvedla inovativni na- 
črtovalski pristop, katerega cilj je bil izvesti program prenove $\mathrm{v}$ celotnem središču mesta in se spoprijeti z njegovo degradacijo z edinstveno in celostno vizijo (Arbaci in Tapada-Berteli, 2012: 292). Ta načrtovalski pristop so po osemdesetih letih 20. stoletja razširili tudi na obrobna območja (Esteban, 2004). Uspešna preobrazba degradiranih urbanih območij je postala splošno prepoznana kot ključen del t. i. barcelonskega modela urbanega razvoja (Monclús, 2003), za katerega je značilna obsežna urbana regeneracija nekdanjih industrijskih zemljišč, ki se pretvorijo v strnjena mestna območja mešane rabe. To preobrazbo omogočajo javne naložbe v javne storitve in prometno infrastrukturo, razpoložljiv visokokakovostni javni prostor in trdna partnerstva med različnimi deležniki (Marshall, 2000; Balibrea, 2001). Med krepitvijo špekulativnega urbanega razvoja v prvem desetletju 21. stoletja so se ta partnerstva spoprijela $\mathrm{z}$ velikimi izzivi, zaradi česar so nekateri avtorji pisali o propadu barcelonskega modela (Delgado, 2004; Degen in García, 2012).

V nasprotju z Barcelono je mestna uprava v Seulu bolj spodbujala urbano prenovo kot pa urbano regeneracijo degradiranih mestnih območij. ${ }^{[4]}$ Od konca sedemdesetih let 20. stoletja je bilo množično rušenje revnih četrti pod vplivom zasebnih naložb ključna značilnost politike urbane prenove v Seulu. Rušenju je navadno sledila prisilna razselitev prebivalcev, ki so morali odstopiti prostor špekulativnim projektom urbane prenove (Kim in Yoon, 2003: 587). Tako je bilo prenovljeno skoraj celotno središče Seula. Zaradi neuspešnega reševanja čedalje večjih družbenih, gospodarskih in okoljskih vprašanj pa je v zadnjem desetletju mestna uprava začela razmišljati o drugačnem načrtovalskem pristopu in se je prenove degradiranih urbanih območij lotila na bolj celosten in vključujoč način (Cho, 2008; Kang, 2012; Križnik, 2013). Urbana regeneracija, ki temelji na lokalni skupnosti in katere cilj je vključiti prebivalce $\mathrm{v}$ načrtovanje in prenovo sosesk, je po letu 2008 postala sestavni del urbanega razvoja Seula (SMG, 2013, 2015b).

Še ena pomembna razlika med Barcelono in Seulom, povezana $s$ preobrazbo degradiranih urbanih območij, se nanaša na institucionalni okvir odločanja, še zlasti, ko gre za odnos med javnimi ustanovami in civilno družbo. Lokalna demokracija se je v Barceloni razvijala skupaj z demokratizacijo katalonske in španske družbe $\mathrm{v}$ sedemdesetih letih 20. stoletja in prve demokratične lokalne volitve so bile leta 1979. V Južni Koreji pa se je lokalna demokracija začela razvijati šele po splošni demokratizaciji družbe, tako da so bile prve demokratične lokalne volitve organizirane šele leta 1995. Vključevanje javnosti, pri katerem javni in zasebni deležniki v procesih odločanja enakopravno sodelujejo z mestno upravo, ima zato v Barceloni daljšso tradicijo kot v Seulu. Zlasti sosedska združenja so imela pomembno vlogo pri preobrazbi barcelonskih degradiranih urbanih območij od sedemdesetih let 20. stoletja, saj so delovala kot široke koalicije lokalnega prebivalstva, ki so zastopale raznolike lokalne interese (Marshall, 2000; Esteban, 2004). Nasprotno so pri urbanem razvoju Seula lahko sodelovali samo lastniki nepremičnin, in sicer prek t. i. združenj za prenovo, ki pa so jih v praksi nadzirale gradbene korporacije $\mathrm{z}$ aktivno podporo mestne uprave (Kim, 2013; Shin in Kim, 2016). Zato je v Seulu pred letom 2008 težko govoriti o institucionaliziranem vključevanju javnosti v preobrazbo degradiranih urbanih območij (Park, 2006; Cho in Križnik, 2017).

\subsection{Barcelona: Območje dejavnosti 22@ v Poblenouju}

Območje dejavnosti 22@, uvedeno leta 2000, je eden največjih projektov urbane regeneracije v Barceloni v zadnjih desetletjih. Osredotoča se na preobrazbo nekdanjega industrijskega območja v industrijskem središču Barcelone v strnjeno sosesko mešane rabe, kjer naj bi t. i. strateške panoge - IKT, medicinska tehnologija, biotehnologija, energetika ter mediji in oblikovanje - nadomestile tradicionalno industrijo. Načrt naj bi torej spodbujal gospodarsko rast, izboljšal gospodarsko konkurenčnost in omogočil preobrazbo Barcelone v konkurenčno globalno mesto. Območje Poblenouja je bilo za to daljnosežno preobrazbo izbrano zaradi bližine mestnemu središcu, majhne gostote pozidave, razpoložljivosti praznih ali neizkoriščnih zemljiščc, dostopnosti, slabo razvitega lokalnega gospodarstva, navidezno nazadujočih socialnih razmer in svoje dolge zgodovine industrializacije (Ajuntament de Barcelona, 2000, 2012; Oliva, 2003).

Industrializacija Poblenouja sega v sredino 19. stoletja, ko so se na tem območju zaradi dobrih prometnih in prostorskih razmer za industrijski razvoj ustanovile velike tekstilne tovarne in obrati strojne industrije. Hkrati s tovarnami je bilo v tem času zgrajenih tudi veliko delavskih sosesk. Poblenou je postal znan kot »katalonski Manchester «, ne samo zaradi svoje značilne industrijske krajine, temveč tudi posebnega načina življenja in lokalne kulture, ki so ju zaznamovali slabe ekonomske razmere, slaba kakovost življenja, nerazvite javne storitve ter močna solidarnost delavskega razreda in družbeni aktivizem (Arxiu Històric del Poblenou, 2001). Družbene in ekonomske razmere so se še poslabšale po šestdesetih letih 20. stoletja, po množični deindustrializaciji območja in preselitvi glavnih tovarn iz mesta. Med letoma 1970 in 2001 je približno četrtina prebivalcev zapustila Poblenou zaradi slabih bivalnih razmer in brezposelnosti (preglednica 1).

Izboljšanje kakovosti življenja $\mathrm{v}$ Poblenouju je bil zato poleg gospodarske konkurenčnosti Barcelone še en pomemben cilj22@. V tem smislu naj bi urbana regeneracija spremenila območje v strnjeno sosesko z mešano rabo, novimi stanovanji, zelenimi površinami, javnimi storitvami in infrastrukturo, ob 
Preglednica 1: Rast števila prebivalcev v Poblenouju

\begin{tabular}{llllllllll}
\hline & 1970 & 1981 & 1986 & 1991 & 1996 & 2001 & 2006 & 2011 \\
\hline prebivalstvo & 64.493 & 61.403 & 57.328 & 58.021 & 55.945 & 58.035 & 69.396 & 77.393 \\
\hline rast & & $-5 \%$ & $-7 \%$ & $1 \%$ & $-4 \%$ & $4 \%$ & $28 \%$ & $4 \%$ \\
\hline
\end{tabular}

Vir: Ajuntament de Barcelona, 2015

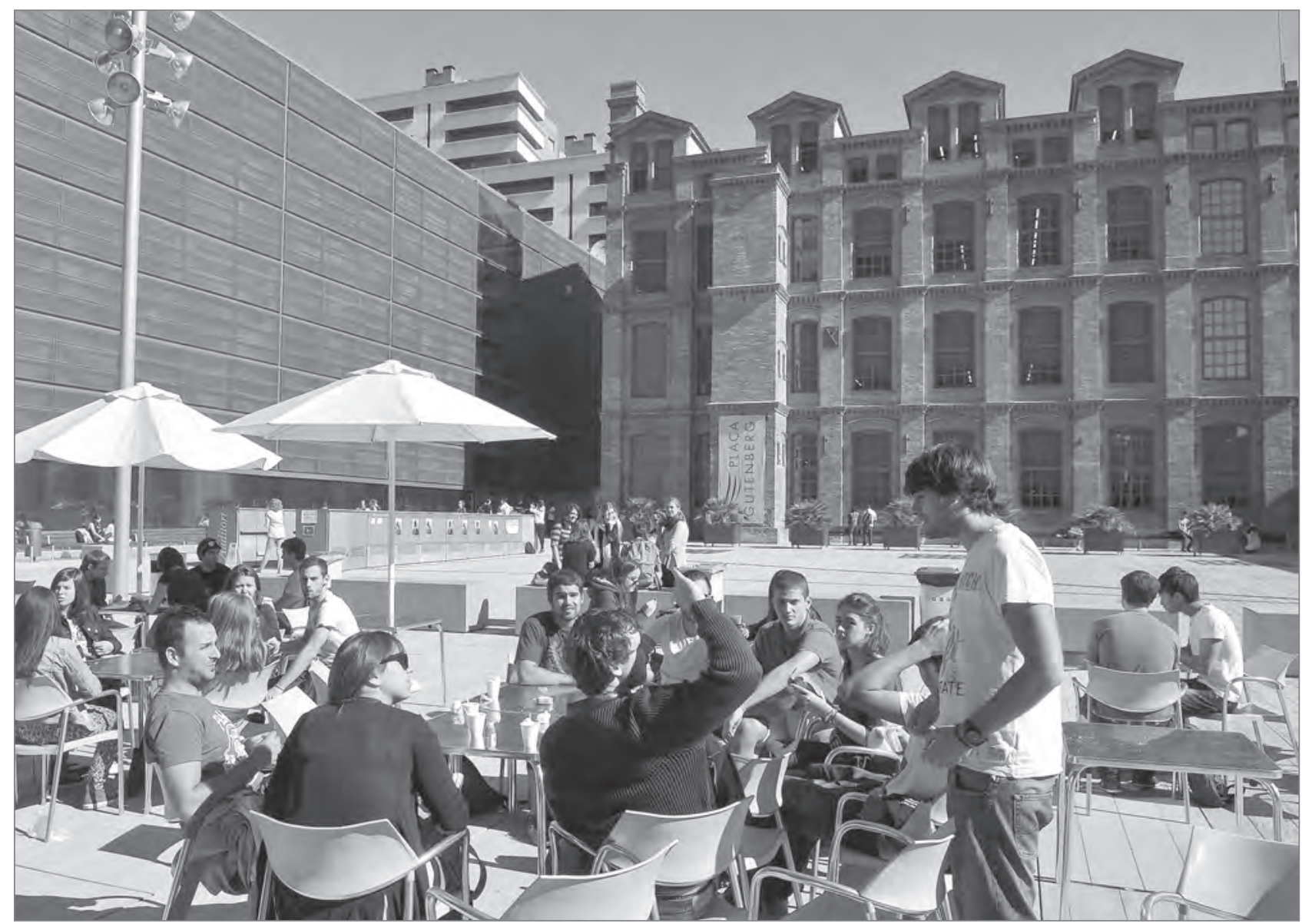

Slika 1: Na območju dejavnosti 22@ naj bi se obstoječa soseska združila z novimi objekti in storitvami (foto: Barcelona Activa, mestni svet Barcelone)

tem bi se legalizirala obstoječa stanovanja. Poleg tega sta bili načrtovani prenova industrijske dediščine in njena vključitev $\mathrm{v}$ novo sosesko (Ajuntament de Barcelona, 2006). To naj bi dosegli predvsem z osredotočanjem na urbani razvoj t. i. strateških območij, ki bi po pričakovanju mestne uprave delovala kot gonilo preobrazbe celotnega območja, zagotavljala koherentnost in omogočala mešano rabo za zadostno neprekinjenost stanovanjskega tkiva (Ajuntament de Barcelona, 2000: $18)$.

Mestna uprava je zato 22@v javnosti predstavila in upravičevala kot projekt izjemnega pomena za prihodnost Poblenouja in mesta v celoti (Ajuntament de Barcelona, 2012). Nekdanji vodja občinske urbanistične službe je jasno predstavil pričakovano vlogo 22@ za dolgoročno gospodarsko rast mesta ter njegov pomen za izboljšanje kakovosti življenja na tem ob- močju. Po njegovem mnenju se mora spoj novih storitvenih dejavnosti vrniti v mesto, v novo, na znanju temelječe mesto. Urbanistični predpisi in gospodarski ukrepi morajo omogočiti in spodbujati okrevanje industrije, da bi lahko obdržali položaj med vodilnimi evropskimi mesti, $z$ novimi zaposlenimi v novih pisarnah, $\mathrm{z}$ dobrimi komunikacijami, skratka, da se bo izboljšala kakovost življenja prebivalcev (Bragado i Acín, 2001: 42).

Veliko teh izhodiščnih ciljev je bilo v zadnjem desetletju doseženih. Poblenou se je spremenil iz na videz propadajoče v živahno sosesko z mešano rabo, kjer se zdi, da so razne družbene in gospodarske dejavnosti dobro povezane (slika 1). Razvijajoče se panoge in storitve, ki temeljijo na znanju in kulturi, izobraževalne in raziskovalne organizacije ter javne ustanove zagotavljajo nove poslovne priložnosti in delovna mesta, prebivalci pa uživajo v novih javnih parkih ter uporabljajo javne storitve 
Preglednica 2: Rast števila prebivalcev v Wangsimniju

\begin{tabular}{lllllllll}
\hline & 1979 & 1984 & 1989 & 1994 & 1999 & 2004 & 2009 & 2014 \\
\hline prebivalstvo & 32.622 & 34.298 & 31.212 & 25.224 & 26.178 & 23.961 & 13.682 & 13.086 \\
\hline rast & & $5 \%$ & $-9 \%$ & $-19 \%$ & $4 \%$ & $-8 \%$ & $-43 \%$ & $-4 \%$ \\
\hline
\end{tabular}

Vir: SMG, 2015a

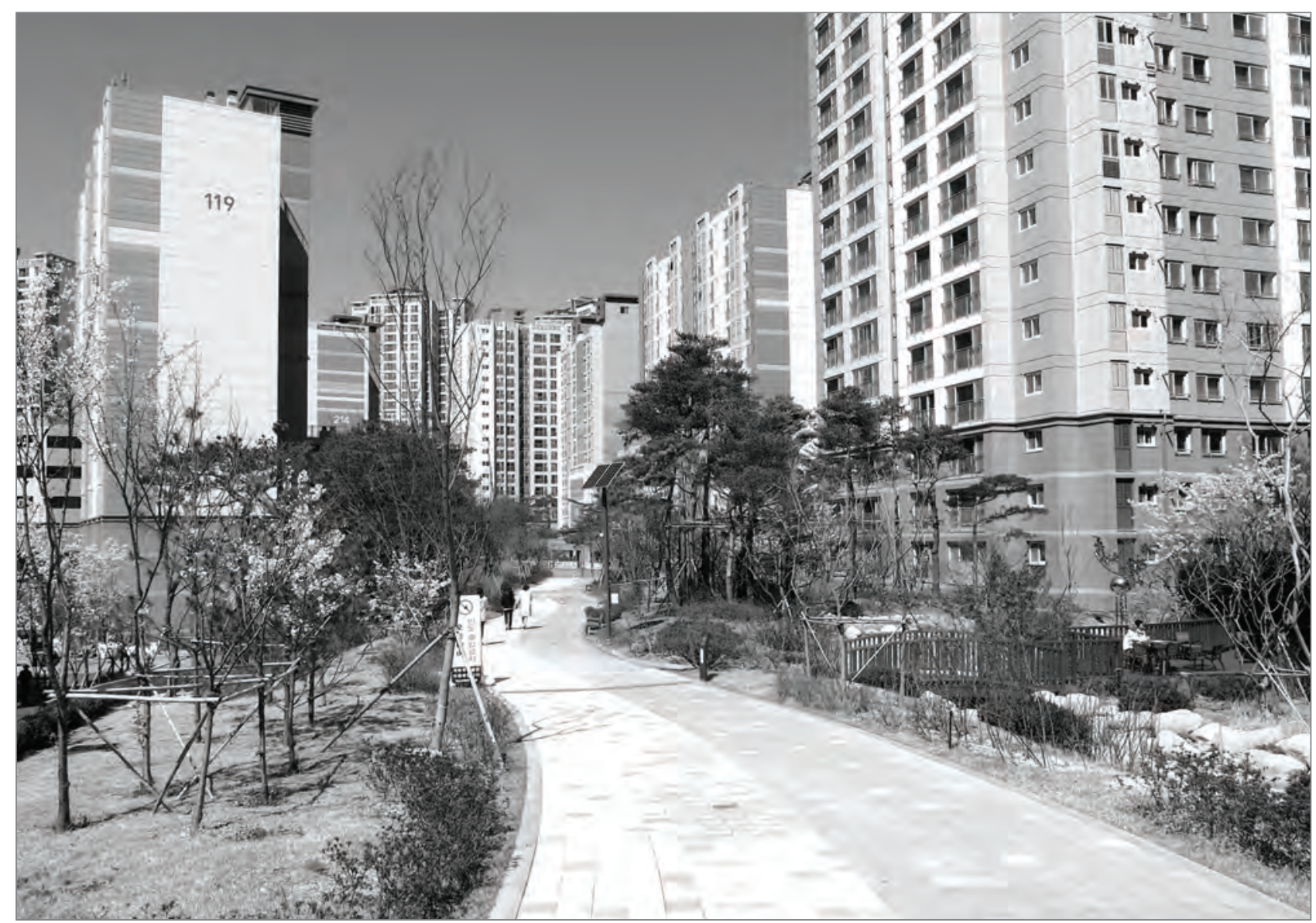

Slika 2: Nova soseska Wangsimni je popolnoma nadomestila staro sosesko (foto: Choi Hongyi).

in infrastrukturo (Ajuntament de Barcelona, 2012). Vendar v nasprotju z začetnimi cilji zagotavljanje teh storitev ni sledilo hitremu ritmu urbanega razvoja, poleg tega tudi varovanje industrijske dediščine pred pričakovano komercializacijo območja ni potekalo po načrtih. Charnock idr. (2014: 200) opozarjajo, da so v resnici preobrazbo večinoma določale najemniške prakse, ki so stremele $\mathrm{k}$ monopolnim najemninam, in ne prizadevanja za spodbujanje industrije, temelječe na znanju, ali izboljšanje kakovosti življenja v Poblenouju. Glede na upad števila delovnih mest $\mathrm{v}$ tradicionalnem industrijskem in storitvenem sektorju, rast stanovanjskih stroškov in izključevanje prebivalcev iz zbirokratiziranih procesov odločanja (Marrero Guillamón, 2010; Dot Jutgla idr., 2012) ne preseneča, da je območje dejavnosti 22@ tudi negativno vplivalo na vsakdanje življenje v Poblenouju in spodbudilo lokalne prebivalce, da začnejo nasprotovati preobrazbi območja (Križnik, 2014).

\subsection{Seul: Nova soseska Wangsimni}

Na prvi pogled se zdi Nova soseska Wangsimni (WNT) za Seul mnogo manj pomembna, kot je 22@ za Barcelono. Urbana prenova majhnega območja mešane rabe, velikega $324.000 \mathrm{~m}^{2}$, v novo stanovanjsko-poslovno sosesko je bila samo eden od podobnih projektov, ki so bili v zadnjem desetletju zgrajeni po vsem mestu. WNT je hkrati tudi eden izmed pilotnih projektov novega mestnega razvoja (ang. New Town Development) - pobude, ki jo je mestna uprava leta 2002 predstavila, da bi uravnotežila urbani razvoj, ustvarila nova delovna mesta in naložbene priložnosti ter izboljšala gospodarsko konkurenčnost Seula (Kim, 2010; Kang, 2012). Z reševanjem vprašanj, povezanih z nenačrtnim širjenjem mesta, stanovanjskimi razmerami, pomanjkanjem infrastrukture in javnih storitev ter čedalje večjo brezposelnostjo, naj bi pobuda odpravila 
Preglednica 3: Dojemanje vsakdanjega življenja in urbanega razvoja v Poblenouju in Wangsimniju (deleži odgovorov)

\begin{tabular}{lll}
\hline & Poblenou & Wangsimni \\
\hline delovno mesto v soseski & $58 \%$ & $66 \%$ \\
\hline pogosto preživljanje koncev tedna v soseski & $66 \%$ & $69 \%$ \\
\hline dnevno srečevanje sosedov & $28 \%$ & $32 \%$ \\
\hline tedensko srečevanje sosedov & $20 \%$ & $41 \%$ \\
\hline dobri odnosi s sosedi & $69 \%$ & $65 \%$ \\
\hline dojemanje soseske kot slabo razvitega območja & $29 \%$ & $64 \%$ \\
\hline dobro poznavanje 22@/WNT & $17 \%$ & $8 \%$ \\
\hline 22@/WNT izraža interese prebivalcev & $6 \%$ & $37 \%$ \\
\hline
\end{tabular}

regionalna neskladja. Osredotočala se je na urbana območja v severnem Seulu, ki jih je mestna uprava obravnavala kot nerazvita, da se gospodarska rast in urbani razvoj uravnotežita s premožnejšim južnim delom mesta (SMG, 2010). Takratni podžupan, odgovoren za javne zadeve in eden idejnih vodij pobude, je poudarjal njen veliki strateški pomen. Po njegovem mnenju je bil glavni razlog za to pobudo dejstvo, da je prišel čas, ko se je bilo treba osredotočiti na revitalizacijo obstoječih sosesk, in ne na gradnjo sindosi. ${ }^{[5]}$ Zato je bilo treba obstoječe mesto prenoviti na podlagi obsežnih, celostnih načrtov, ki upoštevajo splošne potrebe po urbani infrastrukturi (navedeno v Kim, 2010: 95). Wangsimni je bil izbran kot eden od treh pilotnih projektov, ki naj bi pokazali prednosti novega načrtovalskega pristopa, ki celovito obravnava družbene, gospodarske in okoljske vidike urbane prenove (Cho in Križnik, 2017).

Wangsimni je bil nekoč na obrobju Seula. Med hitro industrializacijo mesta $\mathrm{v}$ šestdesetih letih 20. stoletja so se na tem območju nakopičile številne majhne tovarne, ki pa so v naslednjih desetletjih začele počasi, a vztrajno nazadovati (Seoul Museum of History, 2009). Med letoma 1979 in 2004 je Wangsimni izgubil $27 \%$ svojega prebivalstva (preglednica 2). Gospodarsko nazadovanje in slabe bivalne razmere so bili skupaj z dobro dostopnostjo in bližino mestnega središča med glavnimi razlogi, da je mestna uprava to območje izbrala in vključila v pobudo novega mestnega razvoja (SMG, 2005). Kljub temu se zdi, da je bila ta odločitev manj rezultat dejanskih potreb prebivalcev in bolj posledica gospodarskih in političnih interesov mestne uprave, še zlasti v povezavi z bližnjo prenovo potoka Cheonggye. ${ }^{[6]}$ Čeprav projekta med seboj uradno nista bila povezana, je imela prenova potoka Cheonggye neposreden vpliv na izbiro Wangsimnija kot pilotnega projekta, s čimer je želela mestna uprava pokazati pozitivne učinke prenove na degradirana urbana območja (Kim, 2010).

Soseska WNT je bila načrtovana kot območje mešane stanovanjske in poslovne rabe $s$ številnimi javnimi storitvami in obsežnimi zelenimi površinami. Mestna uprava je načrt predstavila kot okolju prijazno skupnost v središču mesta, ki živi v sožitju s potokom Cheonggye, ter kot podeželsko območje v osrčju metropole in novo skupnost, kjer lahko sobivajo prebivalci različnih generacij in družbenih skupin (SMG, 2005: 22). Toda v resnici je urbana prenova povzročila popolno uničenje stare soseske. Zgradila se je nova soseska, ki pa ima malo skupnega z napovedanimi cilji načrta ali interesi deležnikov. Neskladnost načrta in njegove dejanske izvedbe je bila predvsem posledica spremenjenega odnosa mestne uprave, ki je sprva pozvala $\mathrm{k}$ prenovi obstoječih mestnih območij in poskušala prisluhniti različnim deležnikom, na koncu pa je upoštevala le špekulativne interese lastnikov nepremičnin (Cho, 2008; Kim, 2010). Mestna uprava si je tako prizadevala načrt čim prej uresničiti, saj je bil strateškega pomena za mesto (SMG, 2010).

Soseska WNT, ki bo kmalu dokončana in ponuja nove stanovanjske in poslovne prostore ter javne storitve, je močno izboljšala bivalno okolje za nove prebivalce (slika 2). Vendar preobrazba ni spremenila samo bivalnega okolja $\mathrm{v}$ Wangismniju, ampak tudi obstoječo družbeno strukturo in gospodarsko organiziranost soseske, poleg tega je tudi negativno vplivala na vsakdanje življenje na tem območju. Večina nekdanjih prebivalcev se je morala izseliti, obsežne rušitve pa so negativno vplivale tudi na lokalno gospodarstvo in življenje skupnosti ter povzročile izgubo delovnih mest $\mathrm{v}$ tradicionalnih industrijskih in storitvenih sektorih (Kim, 2010). Toda v nasprotju z obsežno mobilizacijo prebivalcev v Poblenouju so se protesti majhnih lastnikov nepremičnin in najemnikov v Wangsimniju začeli pozno, pri čemer so si prizadevali zaščititi predvsem svoje materialne interese, preobrazbi območja pa niso nasprotovali (Križnik, 2014).

\subsection{Posledice in dojemanje urbanega razvoja}

Izsledki ankete in intervjujev razkrivajo, da sta imela Poblenou in Wangsimni pred preobrazbo dobro razvito gospodarsko in skupnostno življenje. To je v popolnem nasprotju s podobo razvrednotenih urbanih območij, ki sta jo javnosti predstavljali mestni upravi, da bi upravičili preobrazbo Poblenouja in Wangsimnija (Ajuntament de Barcelona, 2000; SMG, 2005). 66 \% vprašanih v Poblenouju in $69 \%$ v Wangsimniju je zatrdilo, da so svoj prosti čas pogosto preživljali na tem območju, približno 
polovica vprašanih pa je imela delovno mesto v soseski. Oboje kaže na močno navezanost na kraj (Livingston idr., 2010). $28 \%$ vprašanih v Poblenouju in $32 \%$ v Wangsimniju je svoje sosede srečevalo dnevno, $20 \%$ vprašanih v Poblenouju in $41 \%$ v Wangsimniju pa je sosede srečevalo tedensko. Poleg tega je 69 \% vprašanih v Poblenouju in $65 \%$ v Wangsimniju svoje odnose s sosedi označilo kot odlične ali dobre (preglednica 3). Anketa kaže, da je bila v preteklosti za vsakdanje življenje v Poblenouju in Wangsimniju značilna razmeroma močna družbena kohezija, ki je ključna za družbeno vzdržnost lokalnih okolij (Manzi idr., 2010; Colantonio in Dixon, 2011).

Če bi obe mestni upravi skrbela družbena vzdržnost, bi morali preobrazbi Poblenouja in Wangismnija ohranjati in krepiti družbeno kohezijo območja. Eden od namenov 22@ je bil dejansko legalizirati 4.614 stanovanjskih enot, ki so veljale za nezakonite, ker so bile zgrajene na zemljiščih, namenjenih izključno industrijski rabi, $s$ tem bi nove objekte in storitve povezali z obstoječim družbenim in urbanim tkivom (Ajuntament de Barcelona, 2000). Takšen pristop bi lahko ohranil družbene vezi, navezanost na kraj in skupnostno identiteto $\mathrm{v}$ Poblenouju. Toda veliko teh stanovanjskih stavb je bilo pozneje zaradi špekulativnega urbanega razvoja porušenih. Porušili naj bi se tudi stari industrijski objekti, kar je postalo glavni vir spora med mestno upravo in prebivalci. Ti so industrijsko dediščino dojemali kot pomemben del svojega kolektivnega spomina na zgodovino industrializacije (Grupo de trabajo sobre patrimonio del Fòrum Ribera del Besòs, 2003: 7). Družbena mobilizacija prebivalcev - ki so želeli ohraniti stare tovarne in skupnostno identiteto Poblenouja - je mestno upravo prisilila, da je veliko industrijskih zgradb zaščitila kot kulturno dediščino in jih nazadnje nekaj namenila javni rabi (Ajuntament de Barcelona, 2006).

Prebivalci Poblenouja so se spopadali tudi z razlastitvijo, razselitvijo, upadom števila delovnih mest in rastjo stanovanjskih stroškov (Assemblea de Joves del Poblenou i Assemblea d'Endavant del Poblenou, 2011; Dot Jutgla idr., 2012). Zaradi urbane regeneracije se je v Poblenou v zadnjih desetih letih priselilo več kot 20.000 prebivalcev, kar je enakovredno tretjini vseh prebivalcev, ki so v soseski živeli leta 2000 (preglednica 1). V istem obdobju se je prebivalstvo v okrožju Sant Martí, kjer je Poblenou, povečalo samo za 12 \% (Ajuntament de Barcelona, 2015). Dejansko število novih prebivalcev bi bilo lahko še večje, saj so morali nekateri starejši prebivalci območje zapustiti zaradi naraščajočih stroškov in pomanjkanja cenovno dostopnih stanovanj. Med letoma 2000 in 2010 so v okrožju Sant Martí najemnine naraščale najhitreje v celotnem mestu. $\mathrm{V}$ primerjavi s povprečno rastjo najemnin $\mathrm{v}$ Barceloni, ki je znašala $187 \%$, so se povprečne najemnine v tem okrožju zvišale za $212 \%$ (Ajuntament de Barcelona, 2015). Da bi zagotovila cenovno dosegljiva stanovanja, je nameravala mestna uprava zgraditi 4.000 socialnih stanovanj, od katerih bi jih bilo $25 \%$ namenjenih prebivalcem Poblenouja. Do leta 2010 je bilo dejansko dokončanih samo 1.520 stanovanj (Ajuntament de Barcelona, 2012). Posledično so prebivalci začeli preobrazbo območja dojemati kot načrten poskus mestne uprave, da spremeni obstoječo družbeno strukturo in skupnostno identiteto Poblenouja (L'Associació de Veïns, 2003). To je še zaostrilo nesoglasja med nekaterimi skupinami prebivalcev in mestno upravo (Križnik, 2014).

V nasprotju s Poblenoujem, kjer je večina prebivalcev ostala v soseski in je bil del stanovanjskih in industrijskih zgradb ohranjen, je bil Wangsimni popolnoma porušen. Več kot 10.000 prebivalcev ali približno $45 \%$ celotnega prebivalstva iz leta 2004 je bilo v zadnjem desetletju prisiljenih zapustiti sosesko (preglednica 2). V tem obdobju se je v okrožju Seongdong-gu, v katerem je Wangsimni, število prebivalcev zmanjšalo le malenkostno (SMG, 2015a). Med tistimi, ki so ga zapustili, so bili večinoma najemniki iz gospodinjstev $z$ majhnimi dohodki, zaradi naraščajočih stanovanjskih stroškov pa je malo možnosti, da se bodo po dokončani gradnji WNT vrnili (Lee, 2009; Kang, 2012). V tem pogledu se WNT ne razlikuje dosti od drugih projektov urbane prenove v Seulu, pri katerih se v novo sosesko navadno vrne manj kot $20 \%$ prebivalcev (Shin in Kim, 2016). Takšna množična razselitev prebivalcev lahko izjemno negativno vpliva na družbeno vzdržnost lokalnega okolja (Manzi idr., 2010).

Preobrazba Poblenouja in Wangsimnija je povzročila tudi upad števila delovnih mest $\mathrm{v}$ tradicionalnih industrijskih in storitvenih sektorjih. V Poblenouju je bilo leta 19991.661 industrijskih podjetij ali $23 \%$ vseh podjetij. Potem ko se je leta 2000 začel graditi 22@, je njihovo število do leta 2004 upadlo za 21,6\%, na 1.302, v naslednjih letih pa je še naprej upadalo (Ajuntament de Barcelona, 2008). Čeprav naj bi bilo po navedbah mestne uprave do leta 2010 ustvarjenih 56.000 novih delovnih mest (Ajuntament de Barcelona, 2012), jih večino zasedajo novi prebivalci ali dnevni vozači in so nedosegljiva prebivalcem, ki so delali v tradicionalnih industrijah in storitvah. V Wangsimniju, kjer so leta 2004 industrijska podjetja zajemala 40,5\% vseh podjetij (Seongdong-gu District Office, 2006), so bile razmere še slabše. Podjetja so bila večinoma mala in povezana v industrijske grozde, $v$ katerih so fizična bližina in neposredni stiki ključni za poslovanje (Cho in Križnik, 2017). Po porušenju Wangsimnija teh socialnih in proizvodnih omrežij ni bilo več mogoče ohraniti in številna podjetja so se bila prisiljena preseliti ali končati svoje poslovanje. Leta $2012 \mathrm{v}$ Wangsimniju ni bilo tako rekoč več nobene industrije. Prejšnje raziskave kažejo, da so imeli tradicionalni industrijski in storitveni sektorji v Barceloni in Seulu pomemben vpliv na oblikovanje družbene kohezije v lokalnih okoljih (Nahm, 2001; Marrero Guillamón, 2010). Njihov propad je negativno vplival 
ne samo na gospodarsko, temveč tudi na družbeno vzdržnost Poblenouja in Wangsimnija.

V nasprotju s Poblenoujem, kjer se je družbena mobilizacija prebivalcev proti gospodarskim in družbenim posledicam preobrazbe soseske začela že leta 2000, so prebivalci Wangsimnija sprva podpirali WNT. Čeprav so Wangsimni dojemali kot prijeten kraj za življenje, so sosesko videli tudi kot nerazvito območje, na katerem je primanjkovalo poslovnih priložnosti, zaradi česar so na začetku podpirali načrt prenove (preglednica 3). Kim (2010) navaja, da je bila ta podpora povezana tudi $z$ dejstvom, da je načrtovanje vodila mestna uprava in so zato prebivalci verjeli, da je WNT v javnem interesu. Naraščajoče vrednosti nepremičnin, za katere so prebivalci pričakovali, da jim bodo prinesle finančne koristi, so še dodatno vplivale na njihovo podporo. Med letoma 2002 in 2007 so cene zemljišč v Wangsimniju zrasle za $111 \%$, cene zemljišč v Seulu pa so v istem obdobju v povprečju zrasle za $55 \%$ (Kang, 2007). Po mnenju intervjuvancev je podpora WNT po letu 2006 močno upadla zaradi počasnega izvajanja načrta, finančnih izgub, naraščajočih stanovanjskih stroškov in koruptivnih praks združenj za prenovo. Tako so nekateri lastniki nepremičnin in skupine najemnikov začeli aktivno nasprotovati uresničevanju načrta (Kim, 2010; Križnik, 2014).

Anketa kaže, da so prebivalci Poblenouja in Wangsimnija spoznali (čeprav ne sočasno), da je preobrazba bolj v interesu lastnikov nepremičnin, zasebnih korporacij ali mestne uprave kot pa njih samih (preglednica 3).Dejstvo, da je bil22@ načrtovan brez sodelovanja javnosti in da si je mestna uprava sprva za to le malo prizadevala, je to mnenje samo še okrepilo (Degen in García, 2012). Za večino prebivalcev glavna težava ni bila sama preobrazba, temveč njihova nevključenost v odločanje (Oliva, 2003; Marrero Guillamón, 2010). Hiter urbani razvoj na eni strani in počasna prenova javnih storitev na drugi sta po mnenju intervjuvancev še okrepila njihov negativni odnos do 22@. V nasprotju s Poblenoujem je mestna uprava v Seulu poskušala prebivalce vključiti v načrtovanje WNT. Toda počasen proces vključevanja javnosti, ki je prinesel malo oprijemljivih rezultatov, in zahteve združenj za prenovo po čimprejšnji izgradnji WNT sta mestno upravo prisilila, da je nazadnje prebivalce izključila iz odločanja. To je koristilo špekulativnim lastnikom nepremičnin in zasebnim korporacijam, a je bilo hkrati zelo nepravično do lastnikov nepremičnin, ki so bili proti projektu, ali do najemnikov (Kim, 2010: 154). Lee (2006) ob tem izpostavlja, da je bilo dejansko sodelovanje prebivalcev pod pričakovanji. Nekateri niso imeli časa, drugi pa so morda ugotovili, da imajo zaradi premoči združenj za prenovo v tem procesu v resnici zelo malo besede.

Ne preseneča, da so anketiranci preobrazbo svoje soseske dojemali razmeroma negativno, čeprav mnogi ob tem niso bili natančno seznanjeni s podrobnostmi obeh načrtov. Samo $6 \%$ vprašanih v Poblenouju je verjelo, da 22@ izraža interese prebivalcev, $53 \%$ pa jih je menilo, da je načrt v interesu zasebnih korporacij in mestne uprave. V Wangsimniju je 37 \% vprašanih, večina med njimi je bilo lastnikov nepremičnin, menilo, da je WNT v njihovem interesu (preglednica 3). Ugotovitve ankete in intervjujev kažejo, da sta 22@ in WNT posledično prispevala $\mathrm{k}$ čedalje večjemu nezaupanju prebivalcev $\mathrm{v}$ javne ustanove, kar negativno vpliva na družbeno vzdržnost (Manzi idr., 2010; Dempsey at el., 2011).

\section{Sklep}

22@ in WNT se razlikujeta glede na načrtovalski pristop, deležnike in institucionalni kontekst.22@ je primer celovite dolgoročne urbane regeneracije, ki poskuša združiti nove objekte in storitve z obstoječim družbenim in urbanim tkivom v Poblenouju. Mestna uprava je najprej pripravila in izvedla načrt $\mathrm{v}$ partnerstvu z zasebnim sektorjem brez večjega sodelovanja javnosti. WNT pa je primer kratkoročne urbane prenove, pri katerem je bilo lokalno okolje popolnoma porušeno in nadomeščeno z novo sosesko. Čeprav so bili prebivalci na začetku delno vključeni v odločanje, so zasebne korporacije ob podpori mestne uprave obvladovale celoten proces načrtovanja in izvedbe. Kljub tem precejšnjim razlikam izsledki raziskave kažejo, da sta imela 22@ in WNT z vidika družbene vzdržnosti podobne posledice v lokalnem okolju, še zlasti na družbeno kohezijo in sodelovanje javnosti pri odločanju.

Za vsakdanje življenje v Poblenouju in Wangsimniju so bili včasih značilni močne družbene vezi, navezanost na kraj ter posebna lokalna kultura in skupnostna identiteta. Oba načrtovalska pristopa nista veliko pripomogla k ohranitvi teh družbenih in kulturnih struktur, ki so pomembne za krepitev družbene kohezije na nekem območju. Preobrazba, zaradi katere so se porušila obstoječa stanovanjska in industrijska območja ter je povzročila izgubo delovnih mest $\mathrm{v}$ tradicionalnih industrijskih in storitvenih sektorjih, propad družbenega življenja in naraščanje stanovanjskih stroškov, je družbeno kohezijo v Poblenouju in Wangsimniju oslabila, namesto da bi jo okrepila. Čeprav sta22@ in WNT ustvarila nova delovna mesta, zagotovila nova stanovanja in javne površine ter izboljšala javne storitve in infrastrukturo, vsi od tega niso imeli enake koristi, kar je posledično negativno vplivalo na dojemanje preobrazbe med nekaterimi skupinami prebivalcev. Po njihovem mnenju je bila nova soseska predvsem $\mathrm{v}$ interesu mestne uprave in zasebnih korporacij, kar je posledično oslabilo njihovo zaupanje $\mathrm{v}$ javne ustanove. To zaupanje je dodatno omajala izključitev prebivalcev iz odločanja.

Družbena vzdržnost je večplasten pojem, ki ga je težko ovrednotiti. To je še težje v primerih, kot sta 22@ in WNT, kjer za- 
radi še vedno potekajoče gradnje njenih dolgoročnih posledic še ni mogoče v celoti oceniti. Kljub temu je študija jasno pokazala na premajhno sodelovanje javnosti in oslabljeno družbeno kohezijo, ki sta pomembna vidika družbene vzdržnosti v lokalnem okolju. Čeprav se oba načrtovalska pristopa pomembno razlikujeta, je dejstvo, da 22@ in WNT nista mogla zagotoviti družbene vzdržnosti, v obeh primerih posledica špekulativnega urbanega razvoja, pri katerem se je preobrazba degradiranih urbanih območij uporabila za privabljanje naložb, krepitev gospodarske konkurenčnosti in izboljšanje privlačnosti mesta kot celote. V javnosti sta se oba načrta upravičevala kot navidezno koristna za vse prebivalce, $\mathrm{v}$ resnici pa sta koristila predvsem lastnikom nepremičnin in zasebnim korporacijam. Izsledki raziskave zato kažejo, da lahko špekulativni urbani razvoj negativno vpliva na družbeno vzdržnost, ne glede na uporabljeni načrtovalski pristop. Zaradi še vedno trajajoče preobrazbe Poblenouja in Wangsimnija je predstavljena raziskava omejena. $\mathrm{V}$ tem pogledu bi bilo treba izvesti naknadno študijo, $s$ katero bi opredelili spremembe $\mathrm{v}$ načrtovalskem pristopu $\mathrm{v}$ daljšem obdobju in celovito ocenili dolgoročne vplive preobrazbe na družbeno vzdržnost v Barceloni in Seulu.

\section{Blaž Križnik}

Hanyang University, Graduate School of Urban Studies, Seul, Republika Koreja

E-naslov: blaz@hanyang.ac.kr

\section{Opombe}

[1] $V$ članku se avtor pri poimenovanju opisanih načrtovalskih pristopov v Barceloni in Seulu naslanja na ustaljena angleška izraza in njuni slovenski ustreznici. Čeprav je bil projekt 22@ prvotno predstavljen kot projekt urbane obnove (kat. renovació urbana), se v angleških dokumentih in literaturi omenja kot projekt urbane regeneracije (ang. urban regeneration; Ajuntament de Barcelona, 2000; 2012; Charnock idr., 2014). WNT pa se opisuje kot projekt urbane prenove (ang. urban redevelopment, kor. dosijaegaebal; SMG, 2010; Kim, 2010; Križnik, 2014).

[2] Intervjuji, opravljeni v Barceloni, so vključevali šest predstavnikov civilne družbe (sosedskega združenja Poblenou, zgodovinskega arhiva Poblenou, komisije proti 22@ in foruma Ribera del Besòs), tri predstavnike mestne uprave (barcelonskega mestnega sveta, sveta okrožja Sant Martí in urbanističnega urada Barcelona Regional), enega predstavnika zasebnega sektorja (omrežja 22@) in dva strokovnjaka (enega predstavnika katalonske politehnike UPC in enega predstavnika katalonskega inštituta za napredno arhitekturo laaC). V Seulu je pet intervjuvancev zastopalo civilno družbo (odbor za skupnostni razvoj v Wangsimniju, korejski svet za lokalno agendo 21 , korejsko raziskovalno središče KOCER in inštitut Hope), trije so zastopali lokalno upravo (seulsko metropolitansko upravo in zgodovinski muzej v Seulu), štirje so zastopali zasebni sektor (2. in 3. združenje za prenovo $v$ Wangsimniju, industrijsko in trgovsko združenje Wangsimnija in podjetja Dongyang Purena), vključeni pa so bili tudi štirje strokovnjaki (predstavnik seulskega razvojnega inštituta SDI, predstavnik seulske državne univerze SNU, predstavnik univerze $v$ Seulu UOS in predstavnik univerze Konkook).
[3] Projekta 22@ in WNT sta najbolj vplivala na preobrazbo upravnih enot El Poblenou in Wangsimni 1-dong. Prva je imela leta 2008 30.949 prebivalcev, v drugi pa je leta 2006 živelo 14.099 prebivalcev, kar je bila podlaga za anketno vzorčenje (Ajuntament of Barcelona, 2008; SMG, 2015a).

${ }^{[4]}$ Barcelona in Južna Koreja sta te načrtovalske pristope formalizirali leta 1976, ko je barcelonski mestni svet sprejel splošni metropolitanski načrt, ki je zagotovil pravno podlago za urbano regeneracijo degradiranih urbanih območij, v Južni Koreji pa je bil sprejet zakon o urbani prenovi (Degen in García, 2012; Kim, 2013).

[5] Sindosi je korejsko poimenovanje za nova mesta, ki so bila v zadnjih desetletjih zgrajena v seulski metropolitanski regiji za reševanje težav s pomanjkanjem stanovanj, javnih storitev in infrastrukture v Seulu.

[6] Prenova potoka Cheonggye (ang. Cheonggyecheon Restoration) je še en strateški projekt iz leta 2002, s katerim je bila nekdanja hitra cesta Cheonggye spremenjena v petkilometrski mestni park, skozi katerega teče obnovljena struga potoka Cheonggye. Čeprav je prenova močno izboljšala okoljske razmere v središču Seula in obnovila del zgodovinske in kulturne dediščine, je bila hkrati tarča kritik zaradi pomanjkanja okoljske pristnosti in prispevka h komercializaciji okoliških območij (Križnik, 2011).

\section{Zahvala}

Raziskavo je z raziskovalnimi sredstvi podprla univerza Hanyang (HY2017). Raziskava je bila hkrati financirana v okviru programa Seed za korejske študije, ki poteka pod okriljem ministrstva za izobraževanje Republike Koreje in službe za spodbujanje korejskih študij akademije za korejske študije (AKS-2015-INC-2230013). Osnutek raziskave je bil leta 2014 predstavljen na letnem kongresu AESOP v Utrechtu na Nizozemskem. Avtor se zahvaljuje Petri Očkerl za prevod članka v slovenščino in Simoni Lapanja za pregled prevoda.

\section{Viri in literatura}

Ajuntament de Barcelona (2000): Modification of the PGM (General Municipal Plan) for the renovation of the industrial area of Poblenou. Barcelona.

Ajuntament de Barcelona (2006): Modificaciò del Pla especial de protecció del patrimoni arquitectònic històric-artístic de la Ciutat de Barcelona al Districte de Sant Martí. Patrimoni Industrial del Poblenou. Barcelona.

Ajuntament de Barcelona (2008): Guies estadístiques. Sant Martí en xifres. Barcelona.

Ajuntament de Barcelona (2012): 22@ Barcelona plan. Barcelona.

Ajuntament de Barcelona (2015): Anuari estadístic de la Ciutat de Barcelona 2015. Barcelona.

Alderson, A. S., Beckfield J., in Sprague-Jones J. (2010): Intercity relations and globalisation: The evolution of the global urban hierarchy, 1981-2007. Urban Studies, 47(9), str. 1899-1923. DOI: $10.1177 / 0042098010372679$

Arbaci, S., in Tapada-Berteli, T. (2012): Social inequality and urban regeneration in Barcelona city centre: Reconsidering success. European Urban and Regional Studies, 19(3), str. 287-311. DOI: $10.1177 / 0969776412441110$

Arxiu Històric del Poblenou (2001): El Poblenou: Més de 150 anys d'història. Barcelona. 
Assemblea de Joves del Poblenou i Assemblea d'Endavant (OSAN) del Poblenou (2011): Torres més altes han caigut: el model 22@ al descobert. Raziskovalno poročilo. Barcelona.

Balibrea, M. P. (2001): Urbanism, culture and the post-industrial city: Challenging the "Barcelona model." Journal of Spanish Cultural Studies, 2(2), str. 187-210. DOI: 10.1080/14636200120085174

Beaverstock, J. V., Smith, R. G., in Taylor, P. J. (1999): A roster of world cities. Cities, 16(6), str. 445-458. DOI: 10.1016/S0264-2751(99)00042-6

Bragado i Acín, G. (2001): La renovación del Poblenou: una aproximación urbanística al districto de actividades 22@bcn. V: Ajuntament de Barcelona (ur.): Barcelona, metrópolis mediterrania: Ciudad del conocimiento, str. 28-34. Barcelona.

Brenner N., Marcuse P., in Mayer M. (2012): Cities for people, not for profit: Critical urban theory and the right to the city. London, Routledge.

Cerar, A., in Tančič, M. (2014): Od odziva do pobude: potencial kontributivne participacije. Urbani izziv, 25(1), str. 24-36.

DOI: 10.5379/urbani-izziv-2014-25-01-002

Charnock, G., Purcell, T. F., in Ribera-Fumaz, R. (2014): City of rents: The limits to the Barcelona model of urban competitiveness. International Journal of Urban and Regional Research, 38(1), str. 198-217. DOI: 10.1111/1468-2427.12103

Cho, I. S., in Križnik, B. (2017): Community-based urban development: Evolving urban paradigms in Singapore and Seoul. Singapur, Springer. DOI: 10.1007/978-981-10-1987-6

Cho, M. R. (2008): Seoul-si New Town saeobui pyeonggawa daean mosaek. Journal of Korea Association of Real Estate Law, 17, str. 47-56.

Choe, S. C. (2005): The impacts of globalization on the urban spatial-economic system in Korea. V: Richardson, H. W., in Bae, C. H. (ur.): Globalization and Urban Development, str. 59-78. Berlin, Springer. DOI: 10.1007/3-540-28351-X

Colantonio, A, Burdett, R., in Rode, P. (2014): Transforming urban economies: Policy lessons from European and Asian cities. London, Routledge.

Colantonio, A., in Dixon, T. (2011): Urban regeneration in social sustainability: Best practice from European cities. Oxford, Wiley-Blackwell.

Csomós, G., in Derudder, B. (2013): European cities as command and control centres, 2006-11. European Urban and Regional Studies, 21(3), str. 345-352. DOI: 10.1177/0969776412453149

Degen, M., in García, M. (2012): The transformation of the "Barcelona model": An analysis of culture, urban regeneration and governance. International Journal of Urban and Regional Research, 36(5), str. 10221038. DOI: 10.1111/j.1468-2427.2012.01152.x

Delgado, M. (2004): La otra cara del Fòrum de les cultures S. A. Barcelona, Edicions Bellaterra.

Dempsey, N., Bramley, G., Power, S., in Brown, C. (2011): The social dimension of sustainable development: Defining urban social sustainability. Sustainable Development, 19(5), str. 289-300. DOI: 10.1002/sd.417

Dot Jutgla, E., Pallares-Barbera, M., in Casellas, A. (2012): Gentrificació productiva, desindustrialització i relocalització industrial. Treballs de la Societat Catalana de Geografia, 73, str. 27-52. DOI: 10.2436/20.3002.01.2

Dujon, V., Dillard, J., in Brennan, E. M. (ur.) (2013): Social sustainability. A multilevel approach to social inclusion. London, Routledge.

Esteban, J. (2004): The planning project: Bringing value to the periphery, recovering the centre. V: Marshall, T. (ed.): Transforming Barcelona, str. 111-150. London, Routledge.

Forrest, R., in Kearns, A. (2001): Social cohesion, social capital and the neighbourhood. Urban Studies, 38(12), str. 2125-2143. DOI: 10.1080/00420980120087081
Grupo de trabajo sobre patrimonio del Fòrum Ribera del Besòs (2003): Poblenou, conjunto histórico industrial. El Poblenou, 2003(9), str. 7.

Gugler, J. (ur.) (2004): World cities beyond the West: Globalization, development and inequality. Cambridge, Cambridge University Press.

Hantrais, L., in Mangen, S. (1996): Method and management of cross-national social research. V: Hantrais, L., in Mangen, S. (ur.): Cross-national research methods in the social sciences, str. 1-12. London, Pinter.

Harvey, D. (1989): From managerialism to entrepreneurialism: The transformation in urban governance in late capitalism. Geografiska Annaler, 71(1), str. 3-17. DOI: 10.1080/04353684.1989.11879583

Harvey, D. (2012): Rebel cities. London, Verso.

Ho, D. C. W., Yau, Y., Law, C. K., Poon, S. W., Yip, H. K., in Liusman, E. (2012): Socialna zdržnost pri urbani prenovi: ocena želja skupnosti. Urbani izziv, 23(1), str. 49-63. DOI: 10.5379/urbani-izziv-2012-23-01-005

Irvin, R. A., in Stansbury, J. (2004): Citizen participation in decision making: Is it worth the effort? Public Administration Review, 64(1), str. 55-64. DOI: 10.1111/j.1540-6210.2004.00346.x

Kang, W. (2012): New town project of Seoul, Korea: An evaluation and future directions. Journal of the Korean Urban Management Association 25(4), str. 153-173

Kang, Y. D. (2007): New Town land prices skyrocket 4 to 10 times higher than Seoul average. Yonhap News, 13. 11. 2007.

Kim, J. (2010): Mobilizing property-based interests: Politics of policy-driven gentrification in Seoul, Korea. Doktorska disertacija. Chicago, University of Illinois.

Kim, K. J., in Yoon, I. S. (2003): Urban renewal and change of the 20th century Seoul. V: Kim, K. J. (ur.): Seoul, Twentieth Century: Growth in Change of the Last 100 Years, str. 543-596. Seul, Seoul Development Institute.

Kim, S. H. (2013): Changes in urban planning policies and urban morphologies in Seoul, 1960s to 2000s. Architectural Research, 15(3), str. 133-141. DOI: 10.5659/AIKAR.2013.15.3.133

Križnik, B. (2011): Selling global Seoul: Competitive urban policy and symbolic reconstruction of cities. Revija za sociologiju, 41(3), str. 291312. DOI: $10.5613 /$ rzs.41.3.2

Križnik, B. (2013): Changing approaches to urban development in South Korea: From "clean and attractive global cities" towards "hopeful communities". International Development Planning Review, 35(4), str. 395-418. DOI: 10.3828/idpr.2013.27

Križnik, B. (2014): Local responses to market-driven urban development in global cities. Teorija in praksa, 51, str. 221-240.

Larsen, C. A. (2013) The rise and fall of social cohesion. The construction and de-construction of social trust in the USA, UK, Sweden and Denmark. Oxford, Oxford University Press.

DOI: 10.1093/acprof:oso/9780199681846.001.0001

L'Associació de Veïns (2003): Substitució social al Poblenou. El Poblenou, 9, str. 5.

Lee, J. H. (2006): Dosijaejeongbi chokjineul wihan teukbyeolbeop silhaenge isseo mingwan partnership mosaek: Seoul-si New Townui gyeongheomeul tonghaeseo. V: Seoul Development Institute (ur.): Dosijaejeongbi chokjineul wihan teukbyeolbeop jejeonge tareun Seoul-si New Town saeopui baljeonbangan yeongu, str. 53-90. Seul.

Lee, K. M. (2009): Saengeopttaemune jubyeon teodoljiman ... jibeun julgo binman neuleo. The Hankyoreh, 30. 9. 2009.

Livingston, M., Bailey, N., in Kearns, A. (2010): Neighbourhood attachment in deprived areas: evidence from the north of England. 
Journal of Housing and the Built Environment, 25(4), str. 409-427. DOI: 10.1007/s10901-010-9196-3

Manzi, T., Lucas K., Jones, T. L., in Allen, J. (ur.) (2010): Social sustainability in urban areas: communities, connectivity, and the urban fabric. London, Earthscan.

Marrero Guillamón, I. (2010): The struggle for representation: cultural artefacts and political assemblies in the conflict of Can Ricart, Barcelona. V: Degen, M. in Miles, M. (ur.): Culture and agency: Contemporary culture and urban Change, str. 96-116. Plymouth, University of Plymouth.

Marshall, T. (2000): Urban planning and governance: Is there a Barcelona model?. International Planning Studies, 5(3), str. 299-319. DOI: $10.1080 / 713672855$

Mayer H., in Knox, P. L. (2006): Slow cities: Sustainable places in a fast world. Journal of Urban Affairs, 28(4), str. 321-334. DOI: 10.1111/j.1467-9906.2006.00298.x

Mayer, M. (2007): Contesting the neoliberalization of urban governance. V: Leitner, H., Peck, J., and Sheppard, E. S. (ur.): Contesting neoliberalism: Urban frontiers, str. 90-115. New York, Guildford Press.

Monclús, F. J. (2003): The Barcelona model: An original formula? From "reconstruction" to strategic urban projects (1979-2004). Planning Perspectives, 18(4), str. 399-421. DOI: 10.1080/0266543032000117514

Nahm, K. B. (2001): The spatial structure of unplanned shopping clusters developed along the Cheonggyechon-ro and the emerging new industrial clusters. International Journal of Urban Sciences, 5(1), str. 1428. DOI: $10.1080 / 12265934.2001 .9693485$

OECD (2005): OECD Territorial reviews. Pariz, OECD Publications.

OECD (2009): Promoting entrepreneurship, employment and business competitiveness: The experience of Barcelona. Pariz, OECD Publications.

Oliva, A. (2003): El districte d'activitats 22@. Barcelona, Aula Barcelona.

Park, C. M. (2006): Local governance and community power in Korea. Korea Journal, 46(4), str. 9-32.

Roberts, P., Sykes, H., in Granger, R. (2017): Urban regeneration. 2 izdaja. London, Sage.

Sassen, S. (2001): The global city: New York, London, Tokyo. 2. izdaja. Princeton, Princeton University Press.

Seongdong-gu District Office (2006): Seongdong-gu tonggyeyeonbo 2005. Seul.

Seoul Museum of History (2009): Wangsimni: gonggan, gyeongje, munhwa. Seoul.

Shin H. B., in Kim S. H. (2016): The developmental state, speculative urbanisation and the politics of displacement in gentrifying Seoul. Urban Studies, 53(3), str. 540-559. DOI: 10.1177/0042098014565745

Short, J. R. (2004): Global metropolitan: Globalizing cities in a capitalist world. London, Routledge.

SMG (2005): Development of new towns in balanced development promotion. Seul.

SMG (2010): New Town saeob 7nyeonganui girok. Seul.

SMG (2013): Hamkke mandeulgo hamkke nurineun Seoul-si, Juminchamyeohyeong jaesaengsaeob manual. Seul.

SMG (2015a): Seoul statistical yearbook 2015. Seul.

SMG (2015b): 2025 Seoul-si dosi jaesaeng jeollyag gyehoeg. Seul.

Smith, N. (2002) New globalism, new urbanism: Gentrification as global urban strategy. Antipode, 34(3), str. 427-450.

DOI: 10.1111/1467-8330.00249
Taylor, P. J. (2004): World city network, a global urban analysis. London, Routledge.

Uršič, M., in Križnik, B. (2012): Comparing urban renewal in Barcelona and Seoul: urban management in conditions of competition among global cities. Asia Europe Journal, 10(1), str. 21-39. DOI: 10.1007/s10308-012-0319-1.

Williams, K., in Dair, C. (2007): A framework for assessing the sustainability of brownfield Developments. Journal of Environmental Planning and Management, 50(1), str. 23-40. DOI: 10.1080/09640560601048275

Wolfram, M. (2018): Cities shaping grassroots niches for sustainability transitions: Conceptual reflections and an exploratory case study. Journal of Cleaner Production, 173(1), str. 11-23.

DOI: 10.1016/j.jclepro.2016.08.044 